УДК 615.322+581.16+582.998.16

DOI 10.11603/2312-0967.2017.2.7878

\title{
ДОСЛІДЖЕННЯ УМОВ ЗРОСТАННЯ ТА СПОСОБІВ РОЗМНОЖЕННЯ АCHILLEA MILLEFOLIUM L. TA ACHILLEA DIATANS WALD. ET KIT. В УМОВAX ПРИКAPПATTЯ
}

\author{
(c) О. В. Нейко, А. Р. Грицик, М. В. Мельник \\ Івано-Франківський національний медичний університет \\ farma16@ukr.net
}

\begin{abstract}
Мета роботи. Вивчити особливості розвитку та способи розмноження Achillea millefolium L. та Achillea diatans Wald. et Kit. в умовах культури.

Матеріали і методи. Лабораторну схожість насіння Achillea millefolium L. та Achillea diatans Wald. et Kit. визначали загальноприйнятими методиками. Масу 1000 насінин визначали за допомогою аналітичних ваг. Для визначення розмірів насіння використовували бінокулярний мікроскоп МБС-10. Дослідження вегетативного способу розмноження підземних органів Achillea diatans Wald. et Kit. проводили діленням куща. Вивчено розсадний спосіб вирощування Achillea millefolium L. та Achillea diatans Wald. et Kit. за методикою Б. А. Доспехова.

Результати й обговорення. Досліджено лабораторну і польову схожість насіння Achillea millefolium L. та Achillea diatans Wald. et Kit. при обробці низькими температурами. Вивчено вегетативний та розсадний спосіб вирощування Achillea diatans Wald. et Kit. Проведено фенологічні спостереження за етапами органогенезу Achillea diatans Wald. et Kit. Встановлено, що при вирощуванні розсади рослини відрізняються швидким ростом у кінці першого року вегетації, цвітуть на другий рік життя.

Висновки. За результатами досліджень вивчено насіневу продуктивність, способи розмноження, умови вирощування розсади Achillea millefolium L. та Achillea diatans Wald. et Kit.
\end{abstract}

Ключові слова: Achillea millefolium L.; Achillea diatans Wald. et Kit.; насіння; умови зростання; способи розмноження.

Вступ. В умовах сьогодення постійно зростає попит на сировину та лікарські засоби, які виготовляють на рослинній основі. Вміст у лікарських рослинах комплексу цінних речовин сприяє нормалізації життєво важливих процесів у організмі людини, забезпечує організм мінеральними солями й вітамінами, підтримує на певному рівні обмін речовин. Крім галузі медицини та фрармації, лікарські рослини мають велике значення й для інших галузей народного господарства. У зв'язку з цим, напрямок розвитку ринку лікарських рослин є актуальним і вимагає подальших досліджень у розробці методик культивування та заготівлі сировини згідно з вимогами GACP.

Проведений нами аналіз наукових першоджерел показав, що для видів роду Деревій характерна наявність ряду спільних еколого-фітоценотичних ознак: невибагливість до зволоження та механічного складу ґрунту, відносна стійкість популяцій до антропогенного навантаження, негативна реакція на значне затінення тощо.

Види роду Деревій виступають у різнотравних фрітоценозах на слабкопорушених ділянках, на луках [1]. Частіше зростають розсіяно, зрідка утворють розріджені масиви. Більший врожай дають на багатих азотом ґрунтах [2]. Achillea millefolium L. швидко адаптується в змінених екотопах, активно займає порушені ділянки, здатні тривалий час витримувати несприятливі умови, що надає їм змогу широко розселятись. На досліджуваних територіях Achillea millefolium L. зу- стрічається фррагментарно у багатьох угрупованнях 3 Thymys serpillum L., Matricaria recutita L., Tussilago farfara L., Taraxacum officinale Wigg., Geranium pratense L., Lathyrus laxiflorus L., характеризується в різнотравно-типчаково-ковилових срітоценозах. Фітоценози Achillea millefolium L. 3 високими запасами сировини займають не більше ніж 5 \% площі в рослинному покриві досліджуваних районів. Урожайність повітряно-

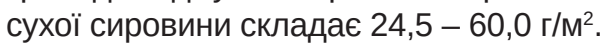

Achillea diatans Wald. et Kit. в межах досліджуваного району має розсіяне поширення. Рідко виступає домінантом в рослинних угрупованнях 3 Mentha longifolia L., Equisetum telmateia Ehrh, Polygonum persicsria L., Geranium sanguineum L. та ін. Урожайність повітряно-сухої сировини складає 10 - 30 г/м².

Проведені дослідження вказують, що запаси сировини видів роду Деревій не достатні для промислової заготівлі як можливої лікарської рослинної сировини.

Тому метою нашої роботи є вивчення особливостей розвитку та способів розмноження Achillea millefolium $\mathrm{L}$. та Achillea diatans Wald. et Kit. в умовах культури.

Дослідження з інтродукції Achillea diatans Wald. et Kit. та вирощування Achillea millefolium L. проводили при консультативній допомозі працівників Державного дендрологічного парку ім. 3. Ю. Павлика Прикарпатського національного університету ім. В. Стефраника. Використовували насіння та посадковий матеріал деревію розсунутого та звичайного, яке заготов-

ISSN 2312-0967. Pharmaceutical review. 2017. № 2 
ляли в Івано-Франківській області в 2011 - 2014 рр. Досліди проводили на колекційних ділянках відділу лікарських рослин у напрямку інтродукції та акліматизації Державного дендрологічного парку ім. 3. Ю. Павлика Прикарпатського національного університету ім. В. Стефраника та на навчально-дослідних ділянках лікарських рослин ІФНМУ.

Матеріали і методи. Лабораторну схожість насіння Achillea millefolium L. та Achillea diatans Wald. et Kit. визначали загальноприйнятими методиками. Біометричні показники насіння визначали за методичними вказівками з насінництва інтродуцентів [3 - 9]. Масу 1000 насінин визначали за допомогою аналітичних ваг. Для визначення розмірів насіння використовували бінокулярний мікроскоп МБС-10. Дослідження вегетативного способу розмноження підземних органів Achillea diatans Wald. et Kit. проводили діленням куща [10]. Вивчено розсадний спосіб виро-

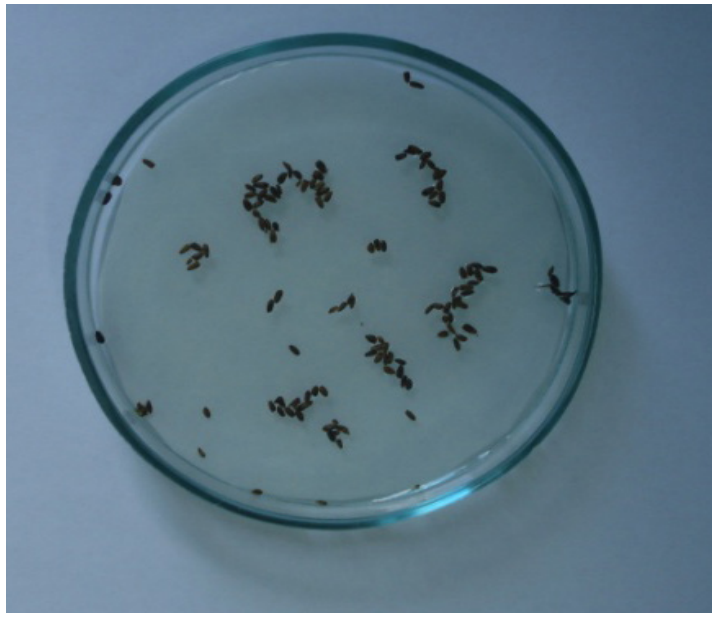

A щування Achillea millefolium L. та Achillea diatans Wald. et Kit. за методикою Б. А. Доспехова [11].

Результати й обговорення. Дослідження лабораторної та польової схожості насіння Achillea millefolium L. та Achillea diatans Wald. et Kit. проводили при обробці низькими температурами. Для виведення насіння із стану спокою і визначення оптимального способу передпосівної обробки, його піддавали холодовій стратифрікації протягом 30 діб (рис. 1).

Пророщування у стерильних умовах проводили запаюванням по 100 насінин у торбинки з синтетичної тканини, на 1 хвилину поміщали у 70 \% етиловий спирт для первинної стерилізації, торбинки з насінням тричі промивали водою очищеною. Після стерилізації насіння висівали на поверхню живильного (0,7\% агар-агар) середовища. Висіяне насіння поміщали в темряву і на світло. Пророщування насіння проводили при температурі $+18-20{ }^{\circ} \mathrm{C}$ (рис. 2).

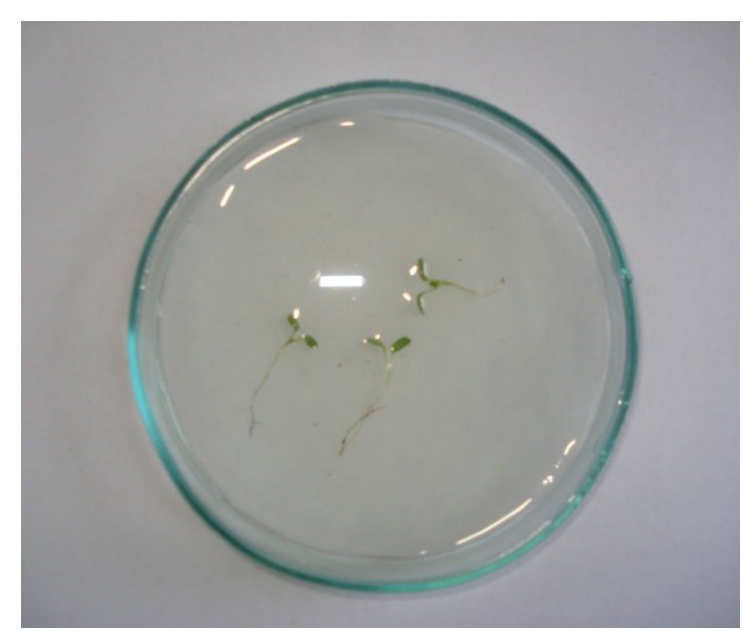

Б

Рис. 1. Способи розмноження видів роду Деревій: А - пророщування насіння у чашках Петрі, Б - утворення сім'ядольних листків.

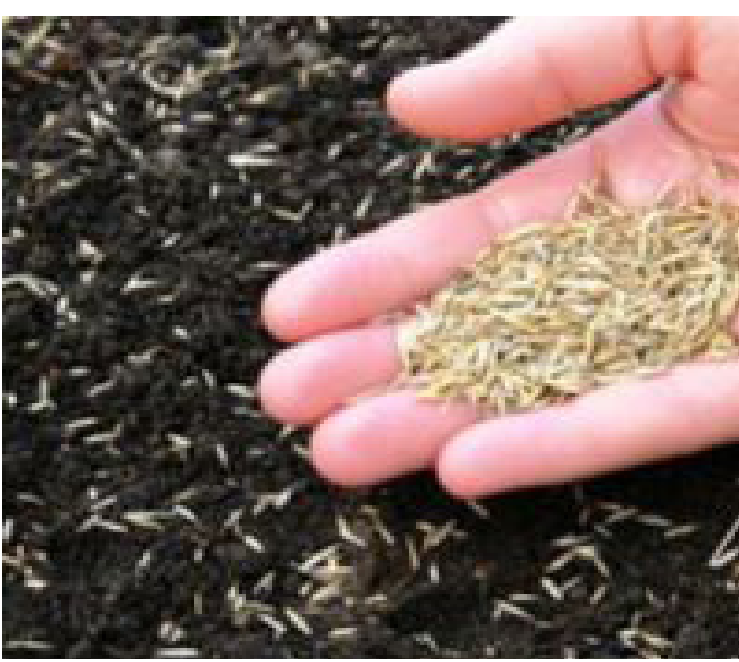

A

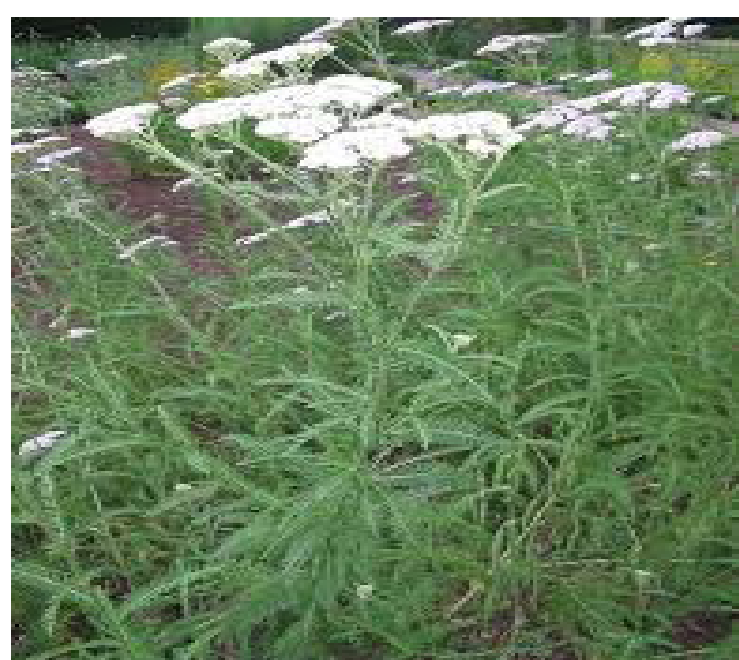

5

Рис. 2. Способи розмноження видів роду Деревій: А - пророщування насіння у лабораторних ящиках, Б - у відкритому ґрунті на дослідних ділянках.

ISSN 2312-0967. Фармацевтичний часопис. 2017. № 2 
Контроль за проростанням проводили з 10-ї доби від дня висіву протягом 30-ти діб при температурі $+18{ }^{\circ} \mathrm{C}$. Лабораторна схожість насіння деревію розсунутого становить $30,8 \pm 0,7 \%$, деревію звичайного - 39,6 \pm 1,7 \%. У насіння деревію розсунутого та звичайного не відбулося суттєвого підвищення показників проростання, оскільки, ймовірно, його насінню властивий більш глибокий морфо-срізіологічний спокій. Під час холодової стратифрікації насіння деревію розсунутого та звичайного у стерильних умовах втрачало схожість внаслідок негативного впливу патогенних мікроорганізмів. Складовою усунення спокою насіння деревію розсунутого та звичайного є дозрівання зародка, який у дрібнішого насіння має менші розміри i, ймовірно, знаходиться на більш ранньому етапі розвитку, а тому потребує більше часу на розвиток. При цьому ураження грибними інфекціями відбувається швидше, ніж з'являються паростки, що впливає на схожість насіння. Насіння, що не проросло, піддали повторній холодовій стратисрікації протягом ще 60 діб, сумарна схожість становила 6,0 0,3 \%. У насіння деревію розсунутого та звичайного проростання після повторної холодової стратифрікації не спостерігалося.

Проведені дослідження свідчать про глибокий морфофрізіологічний спокій насіння Achillea millefolium L. та Achillea diatans Wald. et Kit. Така передпосівна обробка деякою мірою імітує природні умови, у яких частина насіння, яка не проросла в перший рік, проростає наступної весни.

Отже, вивчення насіневого розмноження Achillea millefolium L. та Achillea diatans Wald. et Kit. у лабораторних умовах $є$ передумовою для дослідження способів розмноження.

Achillea diatans Wald. et Kit. розмножували поділом куща. На початку весни акуратно лопатою ділили кущ з добре розвиненими коренями на частини. Кущ висаджували і заглиблювати більше ніж на 2 - 3 см в

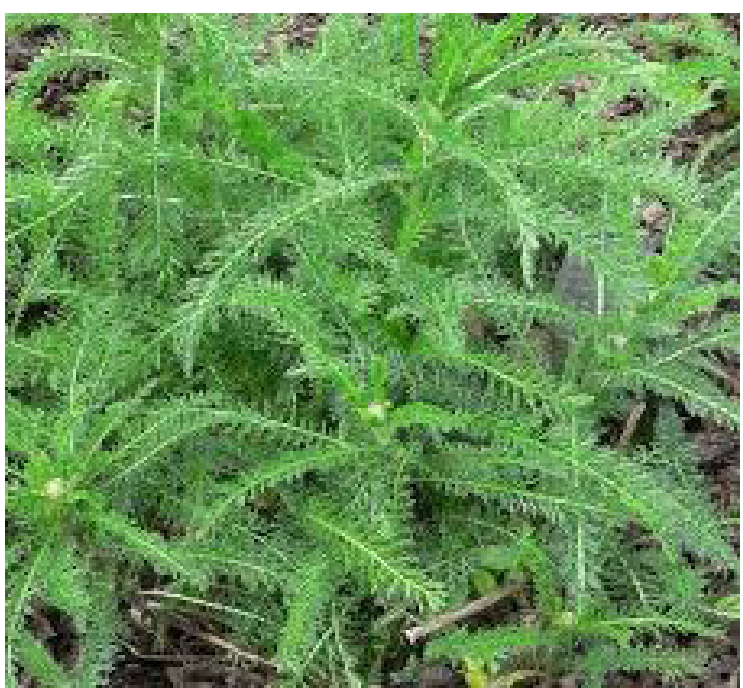

порівнянні з тим, як він зростав до поділу. Висаджували рослини квадратно-гніздовим методом. У перший час приживання рослини потребували частого поливу. Розпушування ґрунту проводили на глибину 4 - 5 см, відступаючи на 8 см від рослини. Протягом вегетаційного періоду проводили 3 - 4 прополки в рядах [11].

Achillea diatans Wald. et Kit., на відміну від інших багаторічних рослин, відрізняється швидким ростом в кінці першого року вегетації - висота рослини становить 30 - 40 см. Цвіте рослина на другий рік життя (рис. 3). Achillea diatans Wald. et Kit. в результаті багаторічної взаємодії з середовищем, виробляє відповідну динаміку сезонного розвитку. В нових умовах проходить процес перебудови рослинного організму, що є підтвердженням акліматизації та інтродукції. Проведені дослідження вказують, що Achillea diatans Wald. et Kit. можна вирощувати в ґрунтово-кліматичних умовах Прикарпаття.

Вирощування розсади Achillea millefolium L. та Achillea diatans Wald. et Kit. проводили за методикою Б. А. Доспехова. Посів насіння Achillea millefolium L. та Achillea diatans Wald. et Kit. здійснювали в кінці зими, оскільки рослина має дуже тривалий вегетаційний період. В кінці лютого готували дрібнозернистий субстрат, змішуючи його в співвідношенні 1:1 з річковим піском. Використовували неглибокий ящик, тому що у деревію розсунутого та звичайного ниткоподібні тонкі коріння. Насіння висівали на відстані від 3 до 5 сантиметрів один від одного на глибину не більше 2 сантиметрів. Після цього пульверизатором зволожували ґрунт. Слідкували за тим, щоб вода не вимила насіння на поверхню ґрунту і не поглиблювала їх. Ящик накривали прозорою плівкою і залишали в теплому і добре освітлюваному місці. Через 10 - 12 діб з'явилися перші сходи. При появі першого справжнього листка саджанці розсаджували методом пікірування, що забезпечує стимуляцію росту і зміцнення

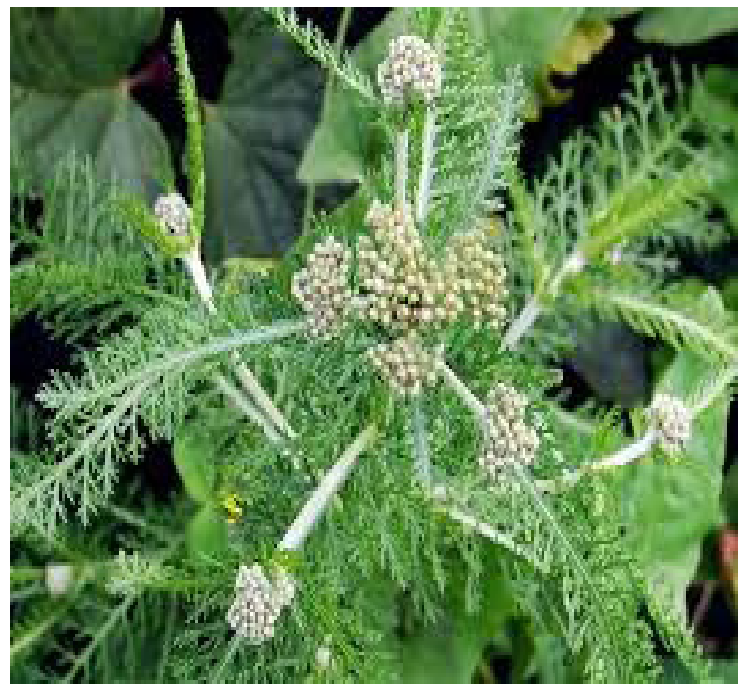

Рис. 3. Achillea diatans Wald. на дослідних ділянках.

ISSN 2312-0967. Pharmaceutical review. 2017. № 2 
коренів. Розсаду висаджували в торф'яні касети, заповнені легким поживним субстратом. Саджанці поливали двічі на тиждень. Коли саджанці Achillea millefolium L. та Achillea diatans Wald. et Kit. досягають висоти 10 - 12 см, їх можна висаджувати на постійне місце зростання. В кінці квітня, коли ґрунт вже достатньо прогрітий сонцем, розсаду висаджували у відкритий ґрунт. Розсаду в торф'яному стаканчику висаджували на глибину близько 10 см, поливали водою і присипали його землею. Achillea millefolium L. та Achillea diatans Wald. et Kit. невибагливі, вони не потребують підживлення, ні регулярного поливу. У спекотну погоду можна зволожувати грунт навколо стебла водою. До кінця серпня Achillea millefolium L. та Achillea diatans Wald. et Kit. поодиноко зацвіли. Масове цвітіння спостерігали через рік.

Висновки. Проведені дослідження підтверджують можливість інтродукції та культивування Achillea millefolium L. та Achillea diatans Wald. et Kit. 3 метою розширення сировинної бази.

\title{
ИССЛЕДОВАНИЕ УСЛОВИЙ РОСТА И СПОСОБОВ РАЗМНОЖЕНИЯ ACHILLEA MILLEFOLIUM L. И ACHILLEA DIATANS WALD. ET KIT. В УСЛОВИЯХ ПРИКАРПАТЬЯ
}

\author{
О. В. Нейко, А. Р. Грицык, М. В. Мельник \\ Ивано-Франковский национальный медицинский университет \\ melnick.mariia@yandex.ru
}

Цель работы. Изучить особенности развития и способы размножения Achillea millefolium L. и Achillea diatans Wald. et Kit. в условиях культуры.

Материалы и методы. Лабораторную всхожесть семян Achillea millefolium L. и Achillea diatans Wald. et Kit. определяли общепринятыми методиками. Массу 1000 семян определяли с помощью аналитических весов. Для определения размеров семян использовали бинокулярный микроскоп МБС-10. Исследование вегетативного способа размножения подземных органов Achillea diatans Wald. et Kit. проводили делением куста. Изучено рассадный способ выращивания Achillea millefolium L. и Achillea diatans Wald. et Kit. по методике Б. А. Доспехова.

Результаты и обсуждение. Исследовано лабораторную и полевую всхожесть семян Achillea millefolium L. n Achillea diatans Wald. et Kit. при обработке низкими температурами. Изучено вегетативный и рассадный способ выращивания Achillea diatans Wald. et Kit. Проведено оренологические наблюдения за этапами органогенеза Асhillea diatans Wald. et Kit. Установлено, что при выращивании рассады растения отличаются быстрым ростом в конце первого года вегетации, цветут на второй год жизни.

Выводы. По результатам исследований изучено способы размножения, условия выращивания рассады Асhillea millefolium L. и Achillea diatans Wald. et Kit.

Ключевые слова: Achillea millefolium L.; Achillea distans Wald. et Kit.; семена; условия роста; способы размножения.

\section{THE STUDY OF THE GROWING CONDITIONS AND PROPAGATION METHODS OF ACHILLEA MILLEFOLIUM L. AND ACHILLEA DIATANS WALD. ET KIT. IN THE CONDITIONS OF CARPATHIAN REGION}

\author{
O. V. Neiko, A. R. Grytsyk, M. V. Melnyk \\ Ivano-Frankivsk National Medical University \\ melnick.mariia@yandex.ru
}

The aim of the work. Examining the features of development and methods of reproduction of Achillea millefolium L. and Achillea diatans Wald. et Kit. in the conditions of culture.

Materials and Methods. A laboratory germination of seeds of Achillea millefolium L. and Achillea diatans Wald. et Kit. was determined by conventional methods. The mass of 1000 seeds was measured using analytical scales. To determine the size of the seed the binocular microscope MBS-10 was used. The research of vegetative method of reproduction of underground parts of Achillea diatans Wald. et Kit. was performed by dividing the bush. The seedling method of Achillea millefolium L. and Achillea diatans Wald. et Kit. growing according to the method of Dospehov B. A. was studied.

Results and Discussion. Laboratory and field germination of seeds of Achillea millefolium L. and Achillea diatans Wald. et Kit under the procession of low temperatures was investigated. The vegetative and seedling methods of growing of Achillea diatans Wald. et Kit were studied an observation of phenological stages of organogenesis Achillea diatans Wald. et Kit was conducted. It was established that during the growing seedlings plants differ by rapid growth at the end of the first year of

ISSN 2312-0967. Фармацевтичний часопис. 2017. № 2 
vegetation; they bloom on the second year of vegetation.

Conclusions. According to the research results the seed productivity, methods of reproduction, growing conditions of seedling of Achillea millefolium L. and Achillea diatans Wald. et Kit. were studied.

Key words: Achillea millefolium L.; Achillea diatans Wald. et Kit.; seeds; growing conditions; propagation methods.

\section{Список літератури}

1. Лікарські рослини: Енциклопедичний довідник / За ред. акад. АН УРСР А. М. Гродзинського. - К. : Українська енциклопедія ім. М.П. Бажана, 1990. - 544 с.

2. Доброчаева Д. Н. Определитель высших растений Украины / Д. Н. Доброчаева, М. И. Котов, Ю. Н. Прокурин. - К. : Фитосоциоцентр, 1999. - 2-е изд. - С. 334-336.

3. Лікарське рослинництво: від досвіду минулого до новітніх технологій // Матеріали другої Міжнародної науково-практичної інтернет-консреренції. - Полтава, 2012. - $161 \mathrm{c}$.

4. Ушкаренко В. О. Особливості елементів технології вирощування льону олійного в умовах півдня України / В. О. Ушкаренко, П. Н. Лазер, О. Л. Рудік // Матеріали Міжнародної наукової конференції. - Херсон, 2012. C. $168-172$.

5. Коренев Г. В. Растениеводство с основами селекции и семеноводства / Г. В. Коренев, П. И. Подгорный, C. Н. Щербак. - [3-е изд., перераб. и доп.]. - М. Агропромиздат, 1990. -575 с.

\section{References}

1. Hrodzynsky A.M. Medicinal herbs: encyclopedic reference book. [Лікарські рослини: Енциклопедичний довідник] Kyiv: Ukrainska entsyklopediia im. M.P. Bazhana, 1990. Ukrainian.

2. Dobrochaeva DN, Kotov MY, Prokuryn Yu.N. Determinant of higher plants of Ukraine [Определитель высших растений Украины]. Kyiv: Fytosotsyotsentr; 1999. Russian.

3. Medicinal plant growing: from past experience to new technologies: Proceedings of the second International Scientific and Practical Internet conference. Poltava; 2012, p. 161. Ukrainian.

4. Ushkarenko VO, Laser PN, Rudik OL. Peculiarities of the elements of technology of oil flax cultivation in conditions of Southern Ukraine: Proceedings of the International Scientific Conference. Kherson; 2012, pp.168-172. Ukrainian. 5. Korenev HV, Podhornyi PY, Shcherbak SN. Crop production with the basics of selection and seed farming. [Растениеводство с основами селекции и семеноводства] Moskva: Ahropromyzdat; 1990. Russian. 6. Vavylov PP, Hrytsenko VV, Kuznetsov VS, Tretyakov NN,
6. Растениеводство / [Вавилов П. П., Гриценко В. В., Кузнецов В. С. и др.]; под ред. Г. С. Павлова. - [5-е изд., перераб и доп.] - М. : Агропромиздат, 1986. - 512 с.

7. Макрушин М. М. Насіннєзнавство польових культур / М. М. Макрушин. - К. : Урожай, 1993. - 288 с.

8. Голубенко А. В. Фізіологічні особливості спокою та проростання насіння деяких видів роду Gentiana L. I А. В. Голубенко // Вісн. Київ. ун-ту. Фізіологія, біохімія та анатомія рослин. - 2010. - Вип. 3. - С. $42-46$.

9. Культивування лікарських рослин на дослідних ділянках ІФДМУ / А. Р. Грицик, М. В. Мельник, Л. М. Грицик [та ін.] // Фармацевтичний часопис. - 2008. - № 2 (6). - С. 72-76.

10. Основи біологічного та адаптивного землеробства : навч. посіб. / П. В. Писаренко, О.О.Горб, Т.В.Невмивако, Ю. С. Голік. - Полтава, 2009. - 312 с.

11. Доспехов Б. А. Методика полевого опыта (с основами статистической обработки результатов исследований) / Б. А. Доспехов. - М. : Агропроиздат, 1985. - 323 с.

Shatylov YS. Rastenievodstvo [Растениеводство]. In: Vavylov PP editor. Moskva: Ahropromyzdat; 1986. Russian. 7. Makrushyn MM Nasinnieyeznavstvo poliovykh kultur [Насіннєзнавство польових культур]. Kyiv: Urozhay; 1993. Ukrainian.

8. Holubenko AV [Physiological peculiarities of calm and germination of seeds of some species of the genus Gentina L.]. Visn. Kyiv. un-tu. Fiziolohiia, biokhimiia ta anatomiia roslyn. 2010;3: 42-6. Ukrainian.

9. Hrytsyk AR, Melnyk MV, Hrytsyk LM, Neyko OV, Nedostup AT, Sikoryn U, Vodoslavsky VM. [Cultivation of medicinal plants in the experimental areas of IFSMU]. Farmacevt chasop. 2008;2: 72-6. Ukrainian.

10. Pysarenko PV, Horb OO, Nevmyvako TV, Holik YuS. Fundamentals of biological and adaptive agriculture: study guide [Основи біологічного та адаптивного землеробства : навчальний посібник]. Poltava; 2009. Ukrainian.

11. Dospekhov, B.A. Methodology of field experience (with the basics of statistical processing of research results) [Методика полевого опыта (с основами статистической обработки результатов исследований)]. Moskva: Ahropromyzdat; 1985. Russian. 